\title{
Gender Inequality: A Case Study in Pakistan
}

\author{
Mahwish Rabia*, Fatima Tanveer, Maida Gillani, Hadiqa Naeem, Shaffaq Akbar \\ Government College Women University, Sialkot, Punjab, Pakistan \\ Email: *mahwish.rabia@gcwus.edu.pk
}

How to cite this paper: Rabia, M., Tanveer, F., Gillani, M., Naeem, H. and Akbar, S. (2019) Gender Inequality: A Case Study in Pakistan. Open Journal of Social Sciences, 7, 369-379.

https://doi.org/10.4236/jss.2019.73031

Received: February 18, 2019

Accepted: March 22, 2019

Published: March 25, 2019

Copyright (C) 2019 by author(s) and Scientific Research Publishing Inc. This work is licensed under the Creative Commons Attribution International License (CC BY 4.0).

http://creativecommons.org/licenses/by/4.0/

(c) (i) Open Access

\begin{abstract}
This paper attempts to investigate the thoughts of men and women on gender inequality in Pakistan. In present study, many aspects are discussed about gender discrimination. The data is collected using survey method, and $63 \%$ people give opinions that women are not treated fairly, while $71 \%$ feel discrimination between men and women in education and 57\% say that parents give more importance to their sons as compared to daughters in Pakistan. The significant results demonstrate that women face gender inequality at home, in education and at workplace. Moreover, the relationship between different variables is calculated by using correlation coefficient, simple and multiple linear regression analysis. The value of $R^{2}=0.54$ illustrates that $54 \%$ variation is explained by the independent variable i.e. parents give more importance to their son and $R^{2}=0.67$ indicates that $67 \%$ variation is explained by the independent variables i.e. inspiration behind working women is, low family income and opportunities to perform social activities. It can be concluded that women are treated cold-heartedly within their homes by parents. Finally, it is suggested that Government and public both should work to promote education and professional development for women. Moreover, for the success of a country, there is need to remove the discriminatory attitude of the society towards the women.
\end{abstract}

\section{Keywords}

Gender Inequality, Education, Society, Professional Development, Correlation, Regression Analysis

\section{Introduction}

Gender inequality means imbalanced behavior and point of view of people based on their gender. Although this issue is, both for men and women but, mostly women are deprived of their rights. As it is a common issue in most of the countries nowadays, but this study is concerned with gender inequality in Pakistan. In most of the areas of Pakistan, women are treated just as wives of houses but 
their emotions, feelings and happiness are not understood. Some people considered that women are lower in status to men both physically and mentally and their lives are totally supervised by men, birth of a son is considered a blessing while the birth of a daughter is a problem. Wife beating is common. The family honor is related with women and their actions.

The people usually assert that girls' education does not bring in earnings but they are wrong. Educating a woman is helpful for the whole generation; an educated woman can bring up her children better and also contribute towards the family income if necessary. Gender discrimination exists mostly in poor educational background. Educated families support woman education because they know that educating a woman actually means educating a generation. So, with the passage of time, the opinion of people will change through education (Zarar et al., [1]).

\section{Review of Literature}

Bukhari et al., [2] examined that in Pakistan just like many Muslim countries, female suffer perception as a result of socio-cultural standards. Financial problems are a major concern for educating the women, but many girls face harassment and criticism from people. Females mostly from rural areas are incapable to convince their families for education and higher education, transportation problems, lack of family support and the narrow mind-set of families make it worse for women. The problem is of male controlling society in Pakistan which leads to perception and yet women are not able to make choices for their rights except for a few in urban areas. In his study he also tells that there are total 342 members in the National Assembly of Pakistan, which includes 60 reserved seats for women. In "Pakistan Today" [3] it was mentioned that Pakistan has been classified the second worst country in the world in the aspect of gender inequality. In Pakistan, 98 percent top managers in banks and other economic organizations and manufacturing units are male. This clearly shows that women are not treated equally as applicants for top management positions. Males are given importance over females in a country where females are more in number. Fleming et al., [4] examined that men's perpetration of violence against women is personally related with gender norms and gender discriminations. Reducing violence against women can result in greater gender equality; this increased gender equivalence, in turn, is essential to better achievement of worldwide development goals. The study also showed that $31 \%$ of men reported as committed physical violence against their wife in their lifetime. Iqbal et al., [5] explained that gender perception is a non-custom security threat to Pakistan and it has suggestions for Pakistan security. Pakistani women are more than half of the total population, but women are treated cold-heartedly within their homes by their partners or leading males through different ways like Domestic Violence, Sawara, Vani, Karo, Kari, killings based on honor, acid throwing, forced marriages etc. Gender discrimination is also deeply fixed in Pakistani society in education and employment areas. It was examined that according to a survey which was 
conducted on 1000 women in Punjab, the $35 \%$ of the women admitted in the Hospitals reported being beaten by their partners and it also shows that at least two women are burned every day in domestic violence occurrence. Pervaiz [6] claimed that women are behind men in almost every field of life. Women have less access to education, physical well-being and work chances. They enjoy very restricted ownership rights. This has controlled them in playing an active role in economic and development events. The gender inequality issue is of very complex nature. It is intensely imbedded in history, culture and customs of a society. Thus a general approach is needed to handle these issues. On one hand, public strategies should be framed in a way which could increase women's access to education, health and work opportunities and on the other hand social enrolment is also needed. In his study the time series data was taken for the period of 1972-2009 in order to analyze the relationship between gender inequality and economic growth in Pakistan. Prudence [7] claimed that discrimination in wages is not only the phenomenon in India but it also exits in a developed country like USA. The findings clearly indicate women registered dietitians in USA earned $\$ 45,258 /$ year while men earned $\$ 50,250$ /year, having a median wage gap of $\$ 4965$. Shellenbarger [8] conducted a study to find out the nature of work undertaken or assigned. Boys tend to be given more physical tasks like lawn mowing and fixing things, while girls are stuck with house cleaning and washing the dishes. Even parents who fight for gender equity in their own marriages find themselves splitting their children's tasks along traditional gender lines. Healy and Zukka [9] studied that only 3 percent of the most highly compensated executives are female, that these positions are held disproportionately by men, and that female executives are more likely to be clustered in particular industry groups.

\section{Research Methodology}

In this research, the population of size 3348 is considered taking BS students, of Government Murray College Sialkot, in which the number of boys are 1869 and girls are 1479. The representative part of the population is called sample. Using Yamane [10], where " $N$ " is the total population size and " $\mathrm{e}$ " is the margin of error, a sample of 357 is determined from the given population. The procedure is given below:

$$
\begin{gathered}
n=\frac{N}{1+N e^{2}} \\
n=\frac{3348}{1+3348(0.05)^{2}}=357
\end{gathered}
$$

\subsection{Sampling Technique}

There are two homogeneous groups one consisting of female students and other consisting of male students. Therefore, sample is selected using stratified random sampling with proportional allocation. The basic formula of stratified random sampling with proportional allocation is described as: 


$$
n_{h}=n * \frac{N_{h}}{N}
$$

where $h$ denotes number of strata (Cochran, [11]).

Using Equation (3) required sample size is calculated as:

$$
\begin{aligned}
& n_{1}=357 * \frac{1869}{3348}=199 \\
& n_{2}=357 * \frac{1479}{3348}=158
\end{aligned}
$$

That is, 199 students are selected from male stratum and 158 students are selected from female stratum.

\subsection{Analysis of Data}

The following statistical techniques are used to analyze the data:

1) Graphs and Frequency Distribution;

2) Correlation Coefficient;

3) Regression Analysis;

4) Mann Witney U-test (Alternative to t-test);

5) Kruskal Wallis Test (Alternative to ANOVA).

\subsection{Significance of the Study}

The significance of the study is:

1) To examine gender inequality in Pakistan.

2) To examine thoughts of men and women about gender inequality.

3) To examine whether women are getting proper rights in the society?

4) To examine whether men and women have the same opportunities and conditions with regard to education, study options and personal development.

5) To examine the discernment in parents behavior towards their son and daughter.

6) To suggest different ways for removing gender inequality from society.

\section{Results and Discussion}

Figure 1 shows that $55.74 \%$ are male respondents and $44.25 \%$ are female respondents. $3.08 \%$ respondents are of 15 - 17 age group, $75.91 \%$ of the respondents are of the age of 18 - 20 years and in age group of 21 or above there are $21 \%$ respondents. $56.30 \%$ of them are from urban area while, $43.69 \%$ of them are from rural areas. These figures also illustrates about the family income of the respondents. It is clear that $35.29 \%$ respondents have income between 10,000 $30,000,39.50 \%$ respondents have income between $31,000-50,000,9.52 \%$ of the respondents have income between $51,000-75,000,9.24 \%$, of the respondents have income between $51,000-75,000,1.12 \%$ of the respondents have income between category 101,000 - 125,000, there are $2.52 \%$ respondents in 151,000 200,000 category and there are $1.68 \%$ respondents have more than 200,000 fam- 
ily income. $17.65 \%$ respondents have 1 - 2 siblings, $41.74 \%$ of the respondents have 3 - 4 siblings, $31.09 \%$ of the respondents have $5-6$ siblings, $7 \%$ respondents have 7 - 8 siblings, $1.68 \%$ of the respondents have $9-10$ siblings and $0.84 \%$ of the total respondents have more than 11 siblings.

\subsection{Pie Charts for Demographic Variables}

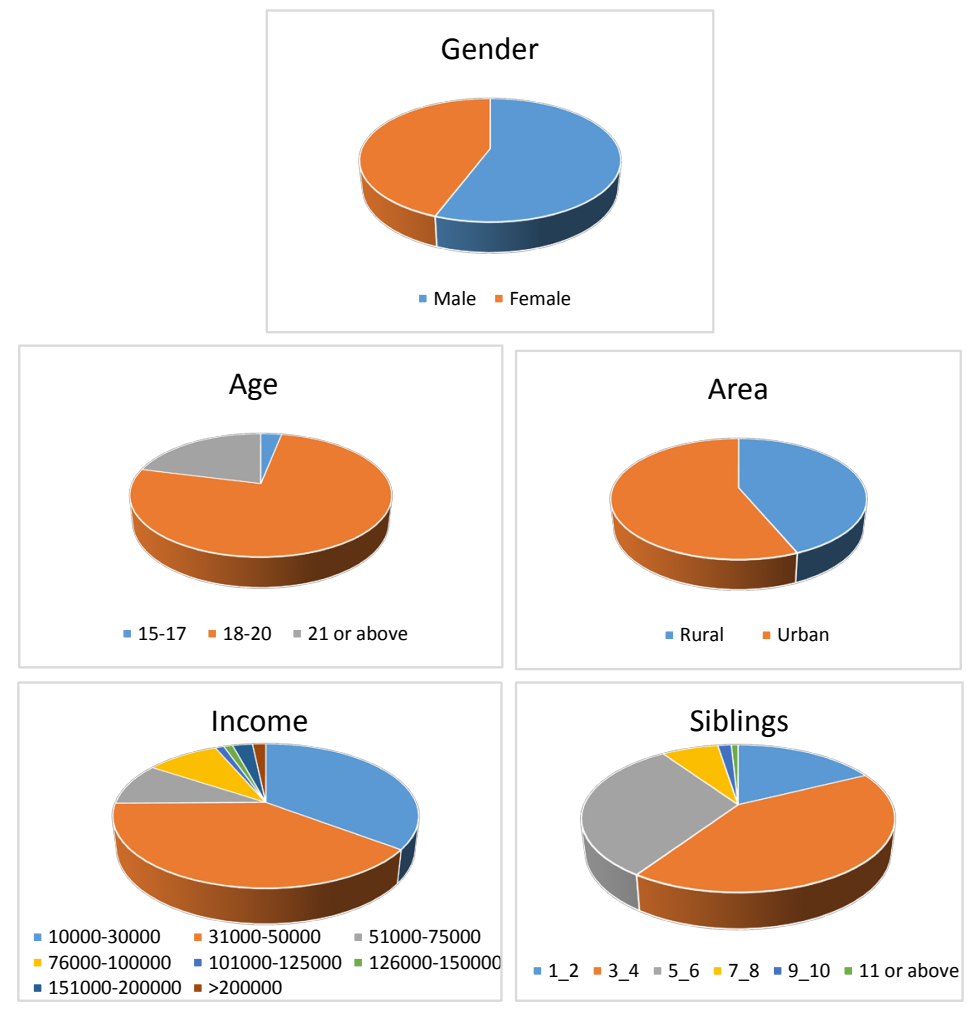

Figure 1. Graphical Representation of Demographic variables.

\subsection{Descriptive Analysis}

Table 1 shows that $63.03 \%$ respondents opinion is that women are treated fairly while, $36.97 \%$ respondents opinion is that women are not treated fairly in Pakis$\tan .30 .53 \%$ respondents are strongly agreed $40.33 \%$ respondents are agreed, $5.04 \%$ are neutral, $17.93 \%$ are disagreed and $6.16 \%$ are strongly disagreed that they feel discrimination between men and women in the field of education. $34.17 \%$ respondents are strongly agreed, $22.40 \%$ are agreed, $2.80 \%$ are neutral $26.89 \%$ respondents are disagreed and $13.72 \%$ are strongly disagreed that parents give more importance to their sons as compared to their daughters. $60.78 \%$ respondents experience gender inequality and $39.22 \%$ respondents did not experience gender inequality. $36.41 \%$ are strongly agreed, $36.41 \%$ are agreed, $12.32 \%$ are neutral, $8.12 \%$ are disagreed and $6.72 \%$ are strongly disagreed that women should work outside their home. $72.79 \%$ respondents are agreed and $26.05 \%$ are not agreed that social activities are welcoming both men and women. $80.95 \%$ respondents agree that men and women are equal and gender doesn't matter and $19.04 \%$ are not agreed that men and women are equal and gender doesn't matter. 
Table 1. Univariate data analysis.

\begin{tabular}{|c|c|c|}
\hline Variable & Categories & $\begin{array}{l}\text { Frequencies } \\
\quad(\%)\end{array}$ \\
\hline In Pakistan do you feel that & Yes & $225(63.03)$ \\
\hline women are treated fairly? & No & $132(36.97)$ \\
\hline \multirow{5}{*}{$\begin{array}{l}\text { Do you feel any discrimination } \\
\text { between men and women in education? }\end{array}$} & Strongly Agree & $109(30.53)$ \\
\hline & Agree & $144(40.33)$ \\
\hline & Neutral & $18(5.04)$ \\
\hline & Disagree & $64(17.93)$ \\
\hline & Strongly Disagree & $22(6.16)$ \\
\hline \multirow{5}{*}{$\begin{array}{l}\text { Do you think that parents give more importance } \\
\text { to their sons as compare to their daughters? }\end{array}$} & Strongly Agree & $122(34.17)$ \\
\hline & Agree & $80(22.40)$ \\
\hline & Neutral & $10(2.80)$ \\
\hline & Disagree & $96(26.89)$ \\
\hline & Strongly Disagree & $49(13.72)$ \\
\hline \multirow{2}{*}{ Did you experience gender inequality? } & Yes & $217(60.78)$ \\
\hline & No & $140(39.22)$ \\
\hline \multirow{5}{*}{$\begin{array}{l}\text { Do you think that women } \\
\text { should work outside their home? }\end{array}$} & Strongly Agree & $130(36.41)$ \\
\hline & Agree & $130(36.41)$ \\
\hline & Neutral & $44(12.32)$ \\
\hline & Disagree & $29(8.12)$ \\
\hline & Strongly Disagree & $24(6.72)$ \\
\hline \multirow{4}{*}{$\begin{array}{l}\text { Do you think that social activities } \\
\text { (championship games, child welfare centers, } \\
\text { leadership, educational trips) } \\
\text { are welcoming both men and women? }\end{array}$} & & \\
\hline & Yes & $264(72.79)$ \\
\hline & No & $93(26.05)$ \\
\hline & & \\
\hline \multirow{2}{*}{ All people are equal and gender doesn't matter. } & True & $289(80.95)$ \\
\hline & False & $68(19.04)$ \\
\hline \multirow{2}{*}{ Men are better leaders than women. } & True & $211(59.10)$ \\
\hline & False & $146(40.89)$ \\
\hline \multirow{2}{*}{ Men make better employees than women. } & True & $185(51.82)$ \\
\hline & False & $172(48.18)$ \\
\hline \multirow{2}{*}{ Women make better educator than men. } & True & $229(64.14)$ \\
\hline & False & $128(35.85)$ \\
\hline \multirow{5}{*}{$\begin{array}{l}\text { Do you feel that is there anything } \\
\text { being done about gender inequality? }\end{array}$} & Strongly Agree & $42(11.76)$ \\
\hline & Agree & $128(35.85)$ \\
\hline & Neutral & $108(30.25)$ \\
\hline & Disagree & $64(17.92)$ \\
\hline & Strongly Disagree & $15(4.20)$ \\
\hline \multirow{5}{*}{$\begin{array}{l}\text { If you think that there is gender inequality } \\
\text { between men and women, so how do you } \\
\text { think that these inequalities can be removed? }\end{array}$} & $\begin{array}{l}\text { Collective efforts by } \\
\text { Govt. }\end{array}$ & $32(8.96)$ \\
\hline & Action taken against & $28(7.84)$ \\
\hline & $\begin{array}{l}\text { harasser } \\
\text { Parents should give } \\
\text { equal importance to } \\
\text { their son and daughter }\end{array}$ & $66(18.48)$ \\
\hline & All of above & $215(60.38)$ \\
\hline & $\begin{array}{l}\text { None (you think that } \\
\text { there is no inequality) }\end{array}$ & $16(4.48)$ \\
\hline
\end{tabular}


$59.10 \%$ people agree and $40.89 \%$ are not agreed that men are better leader than women. $51.82 \%$ people agree and $48.18 \%$ are not agreed that men make better employee than women. $64.14 \%$ respondents are agreed and $35.85 \%$ are disagreed that women make better educator than men. $11.76 \%$ respondents are strongly agree, $35.85 \%$ respondents are agree, $30.25 \%$ are neutral, $17.92 \%$ are disagree and $4.20 \%$ are strongly disagree that there is anything being done about gender inequality. $8.96 \%$ respondents opinion is that gender inequality can be removed by collective efforts by Government, $7.84 \%$ respondents opinion is that gender inequality can be removed by action taken against harasser, $18.48 \%$ respondents opinion is that gender inequality can be removed by collective efforts by parents equal importance to their son and daughter both, $60.38 \%$ respondents agree that gender inequality can be removed by collective efforts by Government, action taken against harasser and parents should give equal importance to their son and daughter both and $4.48 \%$ respondents opinion is that there is no discrimination between men and women.

\subsection{Inferential Analysis}

The process of drawing inferences about population on the basis of sample data is known as inferential statistics.

\subsubsection{Correlation Coefficient}

The main purpose of the correlation analysis is to measure the strength or degree of linear relationship between the two variables. Though these two variables are supposed to be random. There is exact linear relationship between the variables; almost all the correlation coefficients have expected positive signs and the correlation between the variables is greatly strong. The correlation coefficients are given below in Table 2 .

From Table 2, the value of correlation coefficient $(r=0.219, p=0.000<\alpha)$ shows that there is positive correlation between Income and women should work outside their home. It demonstrates that if the income is not adequate then women will work outside their home for job to fulfill their basic needs. In other words, to get more income it's better for women to do more effort.

The value of correlation coefficient $(r=0.382, p=0.001<\alpha)$ shows that there is positive relationship between experience of gender inequality and discrimination between men, women in education, it means that if someone experience gender inequality then he/she will face discrimination in the field of education. That is, parents spend more money on their son's education because they have higher expectation from their sons.

Table 2. Correlation between variables.

\begin{tabular}{cccc}
\hline Variable & Correlation & p-value & Conclusion \\
\hline $\begin{array}{c}\text { Income and women should work outside their home } \\
\begin{array}{c}\text { Experience of gender inequality and discrimination } \\
\text { between men, women in education }\end{array}\end{array}$ & $0.219^{* *}$ & 0.000 & Significant \\
\hline
\end{tabular}

${ }^{* *} \mathrm{P}$-value Significant at $1 \%$ level of significance $(\alpha=0.01)$. 


\subsubsection{Model Analysis}

The simple linear regression model is defined as:

$$
y=\beta_{0}+\beta_{1} x+e
$$

where $\beta_{0}$ is intercept and $\beta_{1}$ slope of the model

$$
y=\text { did you experience gender inequality }
$$

$x=$ Parents give more importance to sons as compare to daughters

In Table 3 the value of $R^{2}=0.54$, it shows that there is $54 \%$ variation is explained by the independent variable. The simple linear regression model is based on two variables where dependent variable is experience of gender inequality and parent's behavior towards children is independent variable. In addition, both the regression parameters $\left(\beta_{0}=1.212, \beta_{1}=0.066\right)$ are significant that is $\mathrm{p}$-value is less than significance value $(\alpha=0.05)$. The fitted regression model demonstrates that reason behind the gender inequality is that parent's behavior is not same for both son and daughter.

The Multiple Linear Regression Model is defined as:

$$
y=\beta_{0}+\beta_{1} x_{1}+\beta_{2} x_{2}+e
$$

where $\beta_{0}$ is intercept and $\beta_{1}$ and $\beta_{2}$ are slopes of the model.

$\mathrm{y}=$ women work outside;

$x_{1}=$ Income;

$x_{2}=$ Social activities (championship games, child welfare centers, leadership, educational trips) are welcoming women.

In Table 4 the value of $R^{2}=0.67$, indicate that $67 \%$ variation is explained by the independent variables. The multiple linear regression model represented by Equation (5) is based on two independent variables and one dependent variable. The dependent variable is women work outside their home and independent variables are income and social activities. In addition, all the regression parameters ( $\left.\beta_{0}=1.284, \beta_{1}=0.368, \beta_{2}=1.168\right)$ are significant that is $\mathrm{p}$-value is less than significance value ( $\alpha=0.05$ ). The fitted regression model demonstrates that motivation behind working women is family income and opportunities to perform social activities.

\subsubsection{Mann Whitney U-Test}

Table 5 checks the significance of variables, discrimination between men and women in education and parent's behavior to their son and daughter, Mann Whitney test is applied. The main concern is to check the point of view of males and females on these variables. From the provided evidence as our p-value is $0.001<\alpha(\alpha=0.05)$ so null hypothesis $\left(\mathrm{H}_{0}\right)$ is rejected and it is concluded that point of view of men and women are not same for these variables.

\subsubsection{Kruskal Wallis Test}

In Table 6 Kruskal Wallis Test is applied considering following variables 1) All people are equal and gender doesn't matter 2) Men are better leader than women 3) Men make better employees than women 4) Women make better educators 
than men. The main concern to apply this test, is to check that point of view of males and females on these variables is same or not. It is clear from the provided evidence as our $\mathrm{p}$-value is $0.000<\alpha(\alpha=0.05)$ so we will reject $\mathrm{H}_{0}$ and conclude that point of view of men and women are not same for these variables.

Table 3. Simple linear regression model.

\begin{tabular}{|c|c|c|c|c|}
\hline Predictor Variable & $\beta$ & S.E & $\mathbf{t}$ & p-value \\
\hline (Constant) & 1.212 & 0.062 & 19.555 & 0.000 \\
\hline $\begin{array}{l}\text { Parents give more importance to } \\
\text { their sons as compared to daughters }\end{array}$ & 0.66 & 0.019 & 3.440 & 0.001 \\
\hline$R^{2}=0.54, S . E=0.084$ & & \multicolumn{3}{|c|}{$F=11.832, \mathrm{p}$-value $=0.001$} \\
\hline \multicolumn{5}{|c|}{$y=1.212+0.66 x$} \\
\hline
\end{tabular}

Table 4. Multiple linear regression model.

\begin{tabular}{|c|c|c|c|c|}
\hline Predictor Variable & $\beta$ & S.E & $\mathbf{t}$ & $\mathrm{p}$-value \\
\hline (Constant) & 1.284 & 0.020 & 6.313 & 0.000 \\
\hline Income & 1.168 & 0.040 & 4.180 & 0.000 \\
\hline $\begin{array}{c}\text { Social activities are welcoming } \\
\text { (championship games, } \\
\text { child welfare centers, leadership, } \\
\text { educational trips) both men and women }\end{array}$ & 0.368 & 0.139 & 2.654 & 0.008 \\
\hline$R^{2}=0.67, S . E=0.199$ & & \multicolumn{3}{|c|}{$F=12.615, \mathrm{p}$-value $=0.000$} \\
\hline \multicolumn{5}{|c|}{$y=1.284+1.168 x_{1}+0.368 x_{2}$} \\
\hline
\end{tabular}

Table 5. Mann Whitney hypothesis test.

\begin{tabular}{cccc}
\hline Null Hypothesis & Test & Sig. & Decision \\
\hline $\begin{array}{c}\text { The point of view of male } \\
\text { and female is same on } \\
\text { discrimination between men } \\
\begin{array}{c}\text { and women in education and parent's } \\
\text { behavior to their son and daughter. }\end{array}\end{array}$ & $\begin{array}{c}\text { Independent Samples } \\
\text { Mann Whitney U Test }\end{array}$ & 0.001 & $\begin{array}{c}\text { Reject the null } \\
\text { hypothesis. }\end{array}$ \\
$\begin{array}{c}\text { The point of view of male and } \\
\text { female is same on anything } \\
\text { being done about gender } \\
\text { inequality and ways to remove } \\
\text { these gender inequality. }\end{array}$ & $\begin{array}{c}\text { Independent Samples } \\
\text { Mann Whitney U Test }\end{array}$ & 0.000 & $\begin{array}{c}\text { Reject the null } \\
\text { hypothesis. }\end{array}$ \\
& & &
\end{tabular}

Table 6. Kruskal wallis hypothesis test.

\begin{tabular}{cccc}
\hline Null Hypothesis & Test & Sig. & Decision \\
\hline $\begin{array}{c}\text { The point of views of males and females } \\
\text { on the variables, all people are equal and } \\
\text { gender doesn't matter, men are better leader } \\
\text { than women, men make better employees than } \\
\text { women and women make better educators than men. }\end{array}$ & $\begin{array}{c}\text { Independent } \\
\text { samples Kruskal } \\
\text { Wallis Test }\end{array}$ & 0.000 & $\begin{array}{c}\text { Reject } \\
\text { the null } \\
\text { hypothesis. }\end{array}$ \\
\end{tabular}




\section{Conclusion}

Gender inequality is an important issue in Pakistan, keeping this in view, the main concern of the study is to know the point of view of males and females about it. The results demonstrate that, the point of view of mostly people is that, parents give more importance to boys as compared to girls and also there is discrimination in the field of education. Mostly backward area people have controversial thoughts about women. More than half of the people in the study experienced gender inequality. The value of correlation coefficient shows that, the more opportunities are given to females for social work, the more they can contribute in the economic growth of the country. It also shows that males and females' point of view about gender inequality are not same. The significant results obtained through simple linear regression show that gender inequality is experienced in society when parents give more importance to their sons. Similarly, the multiple regression illustrates that reason behind working women, outside their homes depends on their low family income and social activities. As gender inequality cannot be removed permanently but with the passage of time it can be eliminated. If government provides opportunities to women for social work and social activities and also encourages their participation so, they will be able to work for the betterment of their society and country.

\section{Suggestions}

The research suggests that there are multiple ways to improve gender balance in the country. It is clearly observed that $60 \%$ people agree that gender inequality can be removed through collective efforts by government, action taken against harasser and parents should give equal importance to their son and daughters (Table 1). Similarly, for the development of country it is necessary that Government should:

1) Provide equal opportunity to both men and women.

2) Promote education and professional development for women.

3) Provide equal rights for women at work place.

4) Ensure health, protection and happiness for all women.

5) Defense against domestic violence and mistreatments.

\section{Conflicts of Interest}

The authors declare no conflicts of interest regarding the publication of this paper.

\section{References}

[1] Zarar, R., Bukhsh, M.M. and Khasheli, A.K. (2017) Causes and Consequences of Gender Discrimination against Women in Quetta City. Arts and Social Sciences Journal, 8, 1-6.

[2] Bukhari, A.H.S., Gaho, G.M. and Soomro, K.H. (2018) Gender Inequality Problems \& Its Solutions in Pakistan. Research Journal of Political Science, 7, 47-58.

[3] Bakhsh, N. (2017) Gender Inequality. Pakistan Today. 
https://www.pakistantoday.com.pk/2017/02/24/gender-inequality-2/

[4] Fleming, P.J., McCleary-Sills, J., Morton, M., Levtov, R., Heilman, B. and Barker, G. (2015) Risk Factors for Men's Lifetime Perpetration of Physical Violence against Intimate Partners: Results from the International Men and Gender Equality Survey (IMAGES) in Eight Countries. PLoS ONE, 10, 1-18.

https://doi.org/10.1371/journal.pone.0118639

[5] Iqbal, H., Afzal, S. and Inayat, M. (2012) Gender Discrimination: Implications for Pakistan Security. IOSR Journal of Humanities and Social Science, 1, 16-25. https://doi.org/10.9790/0837-0141625

[6] Pervaiz, Z., Chani, M.I., Jan, S.A. and Chaudhary, A.R. (2011) Gender Inequality and Economic Growth: A Time Series Analysis for Pakistan. Middle-East Journal of Scientific Research, 10, 434-439.

[7] Prudence, P., Maxine, T. and Noba, D. (2007) Gender-Based Wage Differentials among Registered Dietitians. Health Care Manager, 26, 52-63. https://doi.org/10.1097/00126450-200701000-00007

[8] Shellenbarger, S.U.E. (2006) Boys Mow Lawns, Girls Do Dishes: Are Parents Perpetuating the Chore Wars? Wall street Journal-Eastern Edition, 258. https://www.wsj.com/articles/SB116545148018742855

[9] Healy, J. and Zucca, L.J. (2004) The Gender Equity Gap in Top Corporate Executive Positions. Mid-American Journal of Business, 19, 55-62. https://doi.org/10.1108/19355181200400006

[10] Yamane, T. (1967) Statistics: An Introductory Analysis. Harper and Row, New York.

[11] Cochran, W.G. (1977) Sampling Techniques. John Wiley and Sons, New York. 